\title{
ANKLAGEMYNDIGHEDENS MAGTANVENDELSE \\ OG FORVALTNINGSRETLIGE GRUNDSÆTNINGER
}

\section{Af professor Robert R. SPANo}

\begin{abstract}
The article discusses the interconnection between prosecutorial powers relating to the issuance of indictments or the dismissal of cases at the investigative stage of criminal proceedings and general principles of administrative law. It is argued that decisions by the prosecution essentially entail the use of unilateral governmental authority afforded by statutes providing for discretion. Thus, as a general matter, prosecutorial decision-making must comply with general principles of administrative law to the same extent as other discretionary decisions of governmental organs, at least to the extent that the legislator has not provided for clear statutory exceptions. It is argued however that the method of assessing the legality of prosecutorial decisions in relation to general administrative principles must, at least to some extent, recognise the special nature of prosecutorial powers within administrative law. The article then discusses three perspectives on the question if and to what extent the courts have the authority in criminal cases to examine the conformity of prosecutorial decisions to issue indictments with general principles of administrative law. The author argues that courts may have the authority in limited circumstances to dismiss an indictment without reaching the merits of a criminal case if certain conditions are met. ${ }^{*}$
\end{abstract}

\section{Indledende bemærkninger}

Emnet "lighed for loven" er et bredt emne, og det er ikke så enkelt at begrænse sig til nogle klare holdepunkter. Et er dog sikkert: Inden for strafferetten og strafferetsplejen spiller lighedsprincippet en stor rolle i et demokratisk samfund, som bygger på retsstatsprincippet. Når statsmagten beslutter, at en mand skal være genstand for en straffeprocessuel efterforskning og dernæst tåle en retsforfølgning i form af tiltalerejsning, er det et grundlæggende krav, at politiet og anklagemyndigheden bygger deres beslutninger på saglige hensyn og ikke diskriminerer borgerne. Lighedsprincippet og andre forvaltningsretlige grundsætninger har derfor en overordentlig væsentlig betydning, og de sætter grænser for myndighedsudøvelsen. Endvidere er det særdeles vigtigt, at personer, som sigtes for en strafbar handling, har en realistisk mulighed for at påberåbe sig fejlbehandling, hvis de har mistanke om, at anklagemyndigheden ikke har fulgt lighedsprincippet ved påtalebeslutningen.

\footnotetext{
* Title in English: Prosecutorial Authority and General Principles of Administrative Law. Original in Danish.
} 
I mit foredrag vil jeg først give en kort beskrivelse af de tre afgørelser, som karakteriserer anklagemyndighedens beslutningsproces, når efterforskningen er afsluttet. Det vil sige tiltalerejsning, påtalefrafald og påtaleopgivelse. Næste del handler om de to grundlæggende normer inden for strafferetsplejen - opportunitetsprincippet og legalitetsprincippet - som har væsentlig betydning, når man afgrænser anklagemyndighedens magtanvendelse. Til sidst analyserer jeg spørgsmålet om, hvorvidt anklagerens afgørelser vedrørende færdigbehandling af sager skal være i overensstemmelse med lighedsprincippet og andre forvaltningsretlige grundsætninger på samme måde som andre forvaltningsakter: Anklagemyndighedens afgørelse om f.eks. at rejse tiltale mod $\mathrm{A}$, men at opgive eller frafalde påtale i samme sag vedrørende $\mathrm{B}$, skulle så behandles af domstolene på grundlag af almindelige uskrevne grundsætninger om forvaltningsakters ugyldighed inden for forvaltningsretten, og at det må være et krav, at personen $\mathrm{A}$ kan påberåbe sig en sådan mistanke i den egentlige straffesag mod ham eller hende.

\section{Tiltalerejsning, påtaleopgivelse og påtalefrafald}

Når det angår straffeprocessuelle beslutninger, som følger efter, at efterforskningen er afsluttet, taler man traditionelt om tre typer af afgørelser: Tiltalerejsning, påtaleopgivelse og påtalefrafald.

Påtaleopgivelse er traditionelt set en beslutning om at undlade forfølgning, fordi det bevismæssige grundlag er utilstrækkeligt, eller fordi de retlige betingelser for at pålægge strafansvar ikke er til stede. Påtalefrafald er på den anden side en beslutning om ikke at rejse tiltale, selv om de bevismæssige og retlige betingelser for en fældende dom anses for at være til stede.

Tiltalerejsning er en ensidig og bindende afgørelse om, at anklagemyndigheden har besluttet, at staten skal rejse en straffesag ved domstolen mod en bestemt person eller bestemte personer. Med tiltalerejsning er den egentlige forvaltningssag hos politiet og anklagemyndigheden afsluttet, og sagen har ændret karakter med en ny begyndelse for domstolene. Afgørelse om at rejse tiltale er derfor en forvaltningsakt, som instituerer en ny sag hos et andet statsorgan, hvor de materielle lovregler $i$ deres natur er anderledes end på efterforskningsstadiet eller i påtalefasen.

\section{Opportunitetsprincippet og legalitetsprincippet}

Traditionelt skelner man i nordisk ret mellem, hvorvidt anklagemyndighed udøves efter et legalitets- eller et opportunitetsprincip. I det første tilfælde er det i loven angivet, i hvilke tilfælde tiltale skal rejses og/eller undlades, og anklagemyndigheden er da både berettiget og forpligtet til at rejse eller at undlade tiltale i de angivne tilfælde. I det sidste tilfælde - når anklagemyndigheden udøves efter et opportunitetsprincip - har loven kun angivet de tilfælde, hvor anklagemyndigheden kan rejse (eller undlade) tiltale, og har overladt det til anklagemyndigheden selv at afgøre, om det skal 
ske. Anklagemyndigheden står frit, dvs. er berettiget, men ikke forpligtet til at rejse eller at undlade tiltale. Forskellen mellem de to principper udviskes dog noget, hvor loven formelt gennemfører legalitetsprincippet, men angivelsen af de tilfælde, hvor anklagemyndigheden har pligt til at rejse eller undlade tiltale, er vag og ubestemt. ${ }^{1}$

Det er ikke let at kategorisere den islandske, og nok heller ikke den danske, anklagemyndigheds magtanvendelse på påtaletidspunktet i forhold til et opportunitetsprincip eller legalitetsprincip. Et er dog sikkert: Tiltalebeføjelsen er skønsmassig i forvaltningsretligt henseende.

I en moderne demokratisk retsstat kan en sådan skønsmæssig tiltalebeføjelse ikke være en adgang til helt frit at vælge, om tiltale bør rejses. Anklagemyndighedens valg mellem de tre mulige typer af tiltalebeslutninger i en bestemt sag er, som jeg tidligere har fremhævet, en meget indgribende udøvelse af statsmagt, som er bundet af de samme uskrevne grundsætninger om statens magtanvendelse som andre forvaltningsakter. Anklageren har selvsagt et vist spillerum i denne sammenhæng, og det må også være nødvendigt af ressourcemæssige grunde og andre systemrelaterede grunde.

\section{Anklagemyndigheders tiltalebeslutninger skal være i overensstemmelse med forvaltningsretlige grundsætninger}

Anklagemyndighedens magtanvendelse kan karakteriseres som en ensidig anvendelse af offentlig myndighed over for borgerne. Som et grundlæggende synspunkt er en sådan magtanvendelse bundet af uskrevne grundsætninger inden for forvaltningsretten, som i almindelighed begrænser udøvelsen af skønsmæssige beføjelser af indgribende karakter, som lovgivningsmagten har overladt til de udøvende statsorganer. Anklagerens afgørelse om at rejse tiltale, opgive påtale eller frafalde påtale i en given sag eller i form af en fast praksis er simpelthen en forvaltningsakt, som kan være behæftet med de samme formelle eller materielle ugyldighedsgrunde som andre ensidige og indgribende akter over for borgerne, som forvaltningen anvender på grund af skønsmæssige beføjelser. Det er måske ikke altid helt afklaret, hvordan ugyldighedslæren skal bruges, når det gøres gældende, at en tiltalebeslutning for eksempel er rejst på usaglige hensyn eller diskriminerer borgerne. Men det kan efter min mening ikke være rigtigt, at den forvaltningsretlige ugyldighedslære ikke i princippet gælder om anklagemyndighedens magtanvendelse. Det gaelder, $i$ det mindste hvor lovgivningsmagten ikke klart har begranset rakkevidden for de almindelige forvaltningsretlige grundsatninger inden for strafferetsplejen.

På dette grundlag bliver det næste spørgsmål: Kan en tiltalt person fremsætte krav om, at domstolen i en straffesag erklærer tiltalen ugyldig ved en afvisningskendelse? Eller har domstolene i almindelighed beføjelser til at vurdere tiltalerejsningens gyldighed, hvis det i øvrigt er klart, at sagen kan pådømmes? 
I den sammenhæng kan man nævne tre perspektiver: Den første lægger til grund, at mangler ved tiltalerejsningen i almindelighed ikke har nogen indflydelse på selve retsforfølgningen. Det har på den anden side været hævdet i akademiske kommentarer, at hvis anklageren ikke har fulgt almindelige forvaltningsretlige grundsætninger ved afgørelsen om at rejse tiltale, må dommerens reaktion i straffesagen være begrænset til en dom om straffrihed eller en mildere dom. ${ }^{2}$ Johs. Andenæs har lagt til grund, at de samme krav om saglighed, som gælder for forvaltningen i sin almindelighed, også gælder for anklagemyndigheden. Et andet spørgsmål er, siger han, om mangelfuld skønsudøvelse kan føre til ugyldighedsvirkninger ved domstolene. Andenæs udelukker ikke muligheden for afvisning på grund af forskelsbehandling hos anklagemyndigheden, men siger, at en sådan mulighed i Norge må begrænses til ekstreme tilfælde, f.eks. "hvort det lar seg dokumentere at det dreier seg om en ren hevnakt" . 3

Det er en generel grundsætning i procesretten, at det er domstolenes opgave at overveje deres kompetence i enkelte sager, og dette gælder både for civilprocessen og straffeprocessen. Hvis parterne i en sag indbringer sagen for domstolene på en måde, som er forkert eller ikke er i overensstemmelse med de relevante procesregler eller domstolenes forfatningsretlige position, kan domstolene afvise sagen ex officio. I denne sammenhæng er det vigtigt at forstå, at tiltalerejsningens lovmæssighed på samme måde er et grundlæggende vilkår for domstolenes kompetence i en straffesag. Tiltalebeslutningen er altså grundlaget for den følgende straffesag på samme måde, som stævningen er grundlaget for en civil sag. Hvis tiltalerejsningen er ulovlig ud fra almindelige forvaltningsretlige synspunkter både formelt set og ud fra materielle betragtninger, kan det være tvivlsomt, hvorvidt domstolen har kompetence til at pådømme sagen. Hvis anklagemyndigheden ikke har fulgt almindelige forvaltningsretlige grundsætninger ved dens beslutning om at rejse tiltale, og den tiltalte påberåber sig, at tiltalerejsningen lider af væsentlige mangler, er det dommerens opgave at bedømme tiltalebeslutningens lovmæssighed, i bund og grund på samme måde som $\mathrm{i}$ andre tilfælde af mistanke om forvaltningsakters ugyldighed. Det er efter min mening af principielle grunde ikke rigtigt at begrænse afvisningsmuligheden til, hvad Andenæs kalder "ekstreme tilfælle".

Jeg har sagt før, at med hensyn til anklagemyndighedens samfundsmæssige rolle og karakteren af dens skønsmæssige beføjelser om tiltalebeslutninger kan spørgsmålet om, hvordan almindelige forvaltningsretlige grundsætninger skal bruges af domstolene ved vurdering af tiltalebeslutningen, afhænge af de nærmere omstændigheder. Det vil sige, at det kan være en betingelse, at de mangler, som tiltalebeslutningen skal lide af, skal være væsentlige, og at der må findes tilstrækkelige beviser, som kan lægges til grund i denne henseende, og at anklagemyndigheden ikke for retten på tilfredsstillende måde har kunnet retfærdiggøre sin tiltalebeslutning. 
Det fundamentale spørgsmål må være, hvorvidt mangler ved tiltalebeslutningen kan defineres som en krænkelse af en garantiregel i forvaltningsretlig henseende; det vil sige en mangel, som kan betragtes som formelt eller direkte er knyttet til beslutningens indhold, og som objektivt fører til en risiko for, at usaglige hensyn har haft indflydelse på tiltalebeslutningen. For eksempel har den islandske Højesteret lagt til grund, at hvis det kan statueres, at anklageren objektivt har været inhabil, er det i sig selv en tilstrækkelig grund til, at dommeren straks bør afvise tiltalen. Det er ikke nødvendigt for den tiltalte at bevise, at usaglige hensyn faktisk har ligget til grund for beslutningen om at rejse tiltale, og det har ingen betydning, om anklagemyndigheden kan godtgøre, at selv om der foreligger eventuelle mangler ved tiltalebeslutningen, er der intet i vejen for, at straffesagen procederes for domstolen. Jeg har svært ved at forstå, at når anklagerens objektive inhabilitet kan medføre tiltalens afvisning, som det vistnok er retstilstanden i Island, at der så ikke i princippet skulle gælde det samme, når det kan fastslås ved retsforfølgningen, at tiltalebeslutningen lider af væsentlige mangler, som må karakteriseres som brud på almindelige forvaltningsretlige grundsætninger.

Til sidst må det ikke glemmes, at for den tiltalte er selve retsforfølgningen ved domstolene en meget svær og indgribende oplevelse. Det er derfor ikke tilstrækkeligt, $i$ betragtning af den enkeltes retsbeskyttelse og med hensyn til retfærdighedskravene i demokratiske retsstater, at væsentlige mangler ved tiltalebeslutningen ikke tages fuldt ud $i$ betragtning ved domstolene $i$ en straffesag eller kun tages i betragtning i slutfasen af retsforfølgningen, hvor udfaldet så bliver straffrihed eller en mildere dom.

\section{Noter:}

Bent Unmack Larsen: „Om udøvelse af offentlig anklagemyndighed“. Juristen 1974, s. 467 ff. Eva Smith: Straffeproces. 4. udg., 1999, s. 106; Gorm Toftegaard Nielsen: „Thomsen skulle ikke have været tiltalt". Festskrift til Hans Gammeltoft Hansen, Jurist- og Økonomforbundets Forlag 2004, s. 473-485. Se også fra islandsk ret, Eiríkur Tómasson: „Ákæruvaldið í ljósi jafnræðisreglna“. Rannsóknir í félagsvísindum IV, ritstj. Viðar Már Matthíasson, Félagsvísindastofnun Háskóla - Háskólaútgáfan, 2000, s. 64-65.

3 Johs. Andenæs: Norsk straffeprosess. Bind 1, Universitetsforlaget 2000, s. 307.

\section{Adresse:}

Islands universitet IS - 101 Reykjavik 